\title{
EVALUATION OF APRIL IN SERUM OF PATIENTS WITH HASHIMOTO'S THYROIDITIS
}

\section{AVALIAÇÃO DE APRIL NO SORO DE PACIENTES COM TIREOIDITE DE HASHIMOTO.}

\author{
Adriana Carvalho-Santos ${ }^{1}$, Paulo Travassos Neto ${ }^{2}$, Lia Rafaella Ballard Kuhnert ${ }^{1}$, Marcelo Ribeiro-Alves ${ }^{3}$, Rita \\ Vasconcellos ${ }^{1}$, Luciene Carvalho Cardoso-Weide ${ }^{4}$, Dea Maria Villa-Verde ${ }^{5}$, Carla Eponina Carvalho-Pinto ${ }^{1 *}$ \\ ${ }^{1}$ Immunobiology Department, Biology Institute, Fluminense Federal University, UFF, Niterói, Rio de Janeiro, \\ Brazil. \\ ${ }^{2}$ Medicine School, Endocrinology Unit, Internal Medicine Department, Fluminense Federal University, UFF, \\ Niterói, Rio de Janeiro, Brazil. \\ ${ }^{3}$ HIV/AIDS Clinical Research Center, National Institute of Infectology Evandro Chagas, INI, Fiocruz, Manguinhos, \\ Rio de Janeiro, Brazil. \\ ${ }^{4}$ Medicine School, Pathology Department, Fluminense Federal University, UFF, Niterói, Rio de Janeiro, Brazil. \\ ${ }^{5}$ Laboratory on Thymus Research, Oswaldo Cruz Institute, Fiocruz, Manguinhos, Rio de Janeiro, Brazil \\ * Address for correspondence:
}

\section{ABSTRACT}

Hashimoto's thyroiditis (HT) is an autoimmune and inflammatory disease in which antibodies are directed against the thyroid gland leading to chronic inflammation and hypothyroidism. The autoimmunity against thyroid antigens can be associated to genetic background and environmental factors. Thyroid peroxidase (TPO) and thyroglobulin (TG) are the major autoantigens for characterizing the disease. HT is related to the activation of autoreactive CD4+ T cells, CD8+ cytotoxic $T$ cells and antithyroid antibody producing-B cells. Among several cytokines related to the pathogenesis of $\mathrm{HT}$, a proliferation-inducing ligand (APRIL) has been studied in the context of the establishment and/or maintenance of autoimmune diseases. The role of APRIL in the pathogenesis of HT is still poorly understood. Therefore, the present study aimed to compare APRIL serum concentration in HT patients and healthy donors by ELISA. We observed a significant decrease in APRIL concentration in HT patients when compared to the control group, and a positive correlation between APRIL level and age. Our results suggest that the APRIL molecule can compose the cytokine profile along the inflammatory response in HT, however, other investigations should be proposed to understand its molecular mechanisms via specific
RESUMO

A Tireoidite de Hashimoto (TH) é uma doença autoimune e inflamatória na qual os anticorpos são direcionados contra a glândula tireoide, levando à inflamação crônica e ao hipotireoidismo. A tireóide peroxidase (TPO) e a tireoglobulina (TG) são os principais autoantígenos e esta autoimunidade pode estar relacionada a fatores genéticos e ambientais. A TH é caracterizada pela ativação de células T CD4+ autoreativas, células $T$ citotóxicas CD8+ e células B produtoras de anticorpos antitireoidianos. Entre várias citocinas relacionadas à patogênese da $T H$, um ligante indutor de proliferação (APRIL) tem sido estudado no contexto do estabelecimento e/ou manutenção de doenças autoimunes. O papel da citocina APRIL na patogênese da $\mathrm{TH}$ ainda é pouco compreendido, portanto, o presente estudo teve como objetivo dosar a concentração sérica de APRIL em pacientes com TH e indivíduos saudáveis pela técnica de ELISA. Observamos uma diminuição significativa na concentração de APRIL em pacientes com TH quando comparados ao grupo controle, além de uma correlação positiva entre concentração de APRIL e a idade dos pacientes. Nossos resultados sugerem que a molécula de APRIL pode compor o perfil de citocinas ao longo da resposta inflamatória na $\mathrm{TH}$, no entanto, outras investigações devem ser 
receptors and other regulatory loops.

Key words: Hashimoto's Thyroiditis, APRIL, inflammatory response.

\section{INTRODUÇÃO}

Autoimmune thyroid diseases (AITD) constitute $30 \%$ of all autoimmune conditions and are classified as organ specific diseases. Hashimoto's thyroiditis (HT), described in 1912 by Hakaru Hashimoto, is considered a multifactorial disease in which antibodies are directed against the thyroid gland leading to chronic inflammation and hypothyroidism. The autoimmunity against thyroid antigens can be related to genetic and environmental factors and the disorder is prevalent in individuals aged $>60$ years, with a female/male ratio ranging from $5: 1$ to $10: 1(1,2)$. The diagnosis of HT is based on the increase of anti-thyroid peroxidase (anti-TPO) and anti-thyroglobulin (antiTG) serum levels and the typical clinical signs associated to the change in the ultrasonographic aspects of the thyroid gland $(3,4)$. Although definite diagnostic criteria are not yet available, >20 lgG4positive plasma cells per high-power field and $>30 \%$ IgG4-positive/IgG-positive plasma cells have been proposed as additional diagnostic criteria for $\mathrm{HT}$ (5). The disease is a result of a Th1 immune response which triggers cell mediated immunity and thyroid follicular cell death by apoptosis. Activated antigenspecific T-helper CD4+ cells participate in the activation of intra-thyroid cytotoxic CD8+ T effector cells, B cells, which differentiate and produce autoantibodies (6-8). A prominent role of Th17 ( CD 4+IL-17+) and Treg Iymphocytes (CD4+CD25+highFoxP3+) respectively in the induction and modulation of autoimmune reactions was demonstrated (9).

Several studies indicate that tumor necrosis factors alpha (TNF-alpha) superfamily cytokines such as B cell activation factor (BAFF; also known as BlyS) and a proliferation-inducing ligand (APRIL) play an important role in B cell biology. It has been shown that APRIL has an important role in T-cell independent antibody production, immunoglobulin isotype switching, B cell selection, maturation and survival, as well as IL-10 secretion (10-12). APRIL is produced by a variety of cell types, particularly leukocytes and binds to two surface receptors expressed on $B$ cells: the transmembrane activator propostas para entender seus mecanismos moleculares por meio de receptores específicos e outras alças regulatórias.

Palavras-chave: Tireoidite de Hashimoto, APRIL, resposta inflamatória, Introduction

and calcium modulator and cyclophilin ligand interactor (TACI) and B-cell maturation antigen (BCMA) (13). APRIL, one of the last cloned members of the TNF superfamily, has been shown to stimulate tumor cells and $B$ lymphocyte proliferation in vitro (14). Several lines of evidence suggest that APRIL is important in the establishment and/or maintenance of autoimmune diseases including systemic lupus erythematosus (SLE), rheumatoid arthritis (RA) and HT (15-19). Fernandez and collaborators suggested that APRIL can be a negative regulator of inflammatory diseases mainly due to CD5+ B1 cells activation (17). APRIL has also been investigated as a possible therapeutic strategy for chronic inflammatory diseases. Jagessar and collaborators recently demonstrated that treatment with antiBLyS and anti-APRIL antibodies was effective in Experimental Allergic Encephalomyelitis (EAE), a model for multiple sclerosis (20). In the present work we aimed to estimate the circulating levels of APRIL in HT patients.

\section{MATERIALS AND METHODS SUBJECTS AND CONTROLS}

The study was designed based on exclusion criteria previously determined for the formation of two groups: patients with $\mathrm{HT}$ and healthy individuals as the control group (Table 1). Accordingly, twenty

\begin{tabular}{|c|c|c|}
\hline & HT patients & Healthy subjects \\
\hline $\mathrm{N}$ & 20 & 20 \\
\hline Age range (years) & $15-70$ & $15-70$ \\
\hline \multirow[t]{12}{*}{ Exclusion criteria: } & Diabetes/glucose intolerance & Diabetes/glucose intolerance \\
\hline & Obesity & Obesity \\
\hline & Other thyroid diseases & Thyroid diseases \\
\hline & Other autoimmune diseases & Autoimmune diseases \\
\hline & Pregnancy & Pregnancy \\
\hline & Arterial hypertension & Arterial hypertension \\
\hline & Cardiovascular diseases & Cardiovascular diseases \\
\hline & Acute or chronic infection & Acute or chronic infection \\
\hline & Diagnosis $<5$ years & Use of illicit drugs \\
\hline & $\begin{array}{l}\text { Absence of fibrosis from } \\
\text { physical examination and color } \\
\text { Doppler ultrasonography }\end{array}$ & Smoking and alcoholism \\
\hline & Use of illicit drugs or iodine & \\
\hline & Smoking and alcoholism & \\
\hline
\end{tabular}


female patients with Hashimoto's Thyroiditis, attending the Endocrinology Service of Medicine School of Hospital Universitário Antônio Pedro (HUAP) of Fluminense Federal University (UFF) were included in this study. The study was approved by the University Ethical Committee CEP, CMM/HUAP 313/2011, CAAE 0329.0.285.000-11. Voluntary informed consent was obtained from subjects providing information about the study, peripheral blood collection and applied laboratory techniques. According to the Brazilian Society of Endocrinology and Metabology (SBEM), HT patients were characterized by elevated serum thyroid stimulating hormone (TSH) and decreased free thyroxine (FT4) levels, raised serum anti-TPO and/or anti-TG antibodies, and undetectable TSH receptor antibody (anti-TSHR) (21,22). In addition to these laboratory findings, the diagnosis was confirmed by clinical signs and ultrasonographic images revealing diffuse swelling of the thyroid gland without any other cause. All patients have been followed clinically since the beginning of the study and were receiving different doses of levothyroxine (T4; $25-125 \mathrm{ng} /$ day; median: $76.4 \mathrm{ng} /$ day).

As the control group (C), twenty healthy donors were included (men=3; women=17) with median age of $44.70 \pm 13.64$ years. The inclusion criteria of control individuals were: (i) non-HT and other autoimmune disease; (ii) age similarity $( \pm 5$ years) to patients; (iii) anti-nuclear antibody(ANA) < $1: 80$ and c-reactive protein $(C R P)<0.5 \mathrm{ng} / \mathrm{mL}$.

\section{CLINICAL PARAMETERS}

TSH, FT4, anti-TPO and anti-TG levels were measured in serum by electrochemiluminescence (ICMA, Roche Diagnostics, Platform: Elycsys 2010). For dosage of ANA in serum, the indirect immunofluorescence in human epithelial cells (HEP2) was used, and the c-reactive protein was measured in blood by the agglutination technique. In addition, laboratory tests for autoantibodies to anti-TSHR, CRP; glucose intolerance test (TTG): lipid profile, blood count, liver function, renal functions were performed.

\section{SERUM AND PBMCS ISOLATION}

Blood was collected from all patients with Hashimoto's Thyroiditis and from previously selected healthy donors. Blood samples were kept at room temperature for 30 minutes till they coagulated. After centrifugation at $400 \mathrm{~g}$ for 10 minutes, the serum samples were collected and frozen at $-80^{\circ} \mathrm{C}$ until use.

\section{DETERMINATION OF SERUM LEVELS OF APRIL}

APRIL levels were quantified using Human APRIL Platinum ELISA Kit (eBioscience, Vienna, Austria). According to the manufacturer's instructions, calibration curve, samples, blank and positive control were set in duplicate. APRIL concentration was determined upon the standard curve and the results were expressed by mean \pm SEM of APRIL ( $\mathrm{ng} / \mathrm{mL})$.

\section{STATISTICAL ANALYSIS}

Statistical analysis of data was performed using GraphPad Prism 7.0 software and the results were expressed as mean \pm SEM. The comparison between groups (patients and control) was performed by the non-parametric Mann-Whitney test and the correlations were made through the Spearman correlation. Two-tailed significance levels of less than 0.05 were considered significant.

\section{RESULTS}

\section{PATIENT'S CHARACTERISTICS}

A total of twenty HT patients and twenty healthy donors were included in this study. Patients age (mean \pm SEM), TSH (mIU/L), FT4 $(\mathrm{ng} / \mathrm{mL})$, antiTPO (27 IU/mL) and anti-TG (IU/mL) values are described in table 2 .

Table 2. Clinical features of Hashimoto's Thyroiditis patients.

\begin{tabular}{cc}
\hline Clinical features & $\begin{array}{c}\text { HT patients } \\
(\mathbf{N}=\mathbf{2 0})\end{array}$ \\
\hline Age (years; mean \pm SD $)$ & $50.30( \pm 11.20)$ \\
TSH $(\mathrm{mlU} / \mathrm{L})$ & $3.239( \pm 2.298)$ \\
$\mathrm{FT}_{4}(\mathrm{ng} / \mathrm{dL})$ & $1.484( \pm 1.594)$ \\
Anti-TPO $(\mathrm{IU} / \mathrm{mL})$ & $412.3( \pm 247.2)$ \\
Anti-TG $(\mathrm{IU} / \mathrm{mL})$ & $354.0( \pm 237.6)$
\end{tabular}

SD: standard deviation; $y$ : years; TSH: thyroid stimulating hormone;

TG: thyroglobulin; TPO: thyroid peroxidase;

$\mathrm{FT}_{4}$ : free thyroxine hormone.

\section{APRIL LEVELS IN THE SERUM OF HT PATIENTS}

To evaluate the secretion of APRIL in the context of the inflammatory reaction related to $\mathrm{HT}$, we measured circulating levels of the cytokine. Our results revealed a significant decrease in APRIL in HT patients compared to controls. APRIL concentration for patients with $\mathrm{HT}(\mathrm{n}=20)$ was 6,531 $\pm 0,6807 \mathrm{ng} /$ $\mathrm{mL}$, whereas the concentration for healthy controls $(n=20)$ was $17,52 \pm 2,41 \mathrm{ng} / \mathrm{mL},(p=0.0013$, Figure 


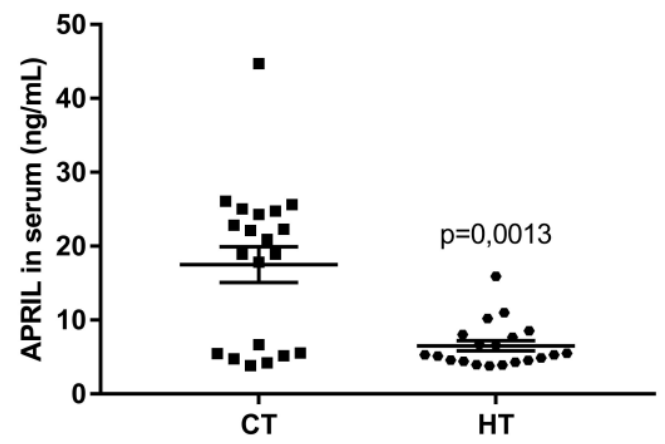

Figure 1. Serum levels of APRIL in Hashimoto's Thyroiditis patients (HT) and control (CT). APRIL serum levels $(\mathrm{ng} / \mathrm{mL}$ ) of control $(n=20$, squares) and $H T$ patients ( $n=20$, circles) groups quantified by ELISA. Difference of means was observed between groups $H T(6,531 \pm 0,6807)$ and $C T(17,52$ $\pm 2,41$ ), $p=0.0013$. The results were expressed by mean \pm SEM and, the comparison between each study group was done using non- parametric Mann-Whitney $\mathrm{U}$-test. $\mathrm{P}<0.05$ was considered significant.

CORRELATION BETWEEN APRIL AND AGE,

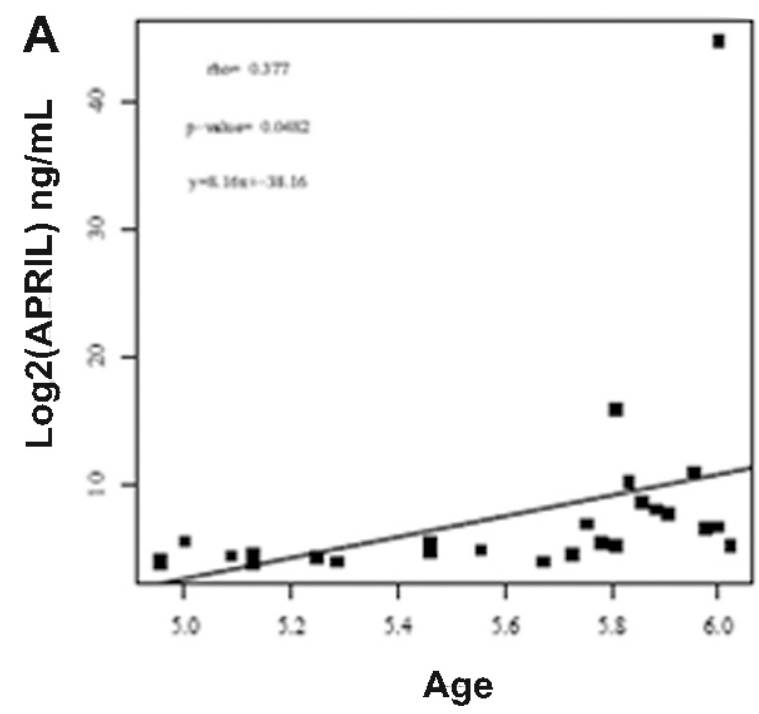

Figure 2. Correlation between the serum levels of APRIL and age, antiTPO and ant-TG in Hashimoto's Thyroiditis. Log-Normalized (base $=2$ ) APRIL serum levels $(\mathrm{ng} / \mathrm{mL}$ ) quantified by ELISA ( $y$-axis) of HT patients (black squares; $\mathrm{n}=20$ ) showed a non-correlation with anti-TPO ( $r h o=0.16 ; p=0.50)$ and anti-TG (rho=0.059; $p=0.804), B$ and C, respectively. But, it showed a positively correlation between APRIL levels and age in both groups $(\mathrm{rho}=0.415 ; \mathrm{p}=0.0078 ; \mathrm{A})$.

\section{AUTOANTIBODY ANTI-TPO AND ANTI-TG}

APRIL levels showed a positive correlation with age $\left(r^{2}=0.2804, p=0.0002\right.$, Figure $\left.2 A\right)$. According to the Brazilian Society of Endocrinology and Metabology (SBEM) guidelines, anti-TPO and anti-TG serum levels are important for clinical classification of HT (22). We evaluated the correlation between these markers with serum levels of APRIL. Our data indicated that there is no significant correlation between circulating levels of APRIL with anti-TPO $\left(r^{2}=0.11126 ; p=0.5775\right)$ or anti- 
TG $\left(r^{2}=0.0195 ; p=0.8847\right)$ serum levels in HT patients (Figure 2B, C).

DISCUSSION

APRIL, a cytokine member of the TNF- $\alpha$ family, regulates $B$ cell activity and can be an important molecule in the establishment and/or maintenance of chronic inflammatory autoimmune diseases $(15,18,19,23,24)$. This cytokine can be produced by a variety of myeloid and nonmyeloid cells, and binds to BCMA and TACl receptors. Both are expressed on $B$ lymphocytes, while $\mathrm{TACl}$ was also detected on a subset of activated T lymphocytes (25). Therefore, APRIL plays an important role in the modulation of B cell activity, such as T-cell independent antibody secretion, immunoglobulin isotype switching and in the selection, maturation and survival of B cells $(26,27)$. Changes in the level of APRIL and its receptors have been described in many autoimmune disorders (28), but the role of APRIL in $\mathrm{HT}$ is still poorly understood. Our present study aimed to determine APRIL serum concentration of patients with Hashimoto's Thyroiditis, evaluating possible correlations with patient's age, anti-TPO and anti-TG levels.

$\mathrm{HT}$ is one of the most prevalent human autoimmune diseases, responsible for high morbidity in women. The antithyroid inflammatory reaction in $\mathrm{HT}$ is enhanced by several mechanisms, counting on the participation of autoreactive $C D 4+T$ cells, CD8+ cytotoxic T cells and anti-thyroid antibodies producing-B cells. An influx of lymphoid cells, dendritic cells and macrophages into thyroid occurs as a consequence of inflammatory events (3).

The HT patients tested in the present study were selected based on similar thyroid histopathological score, TSH and FT4 levels.

The concentration levels of APRIL in the HT patients showed a significant decrease when compared to control group (Fig 1). Likewise, similar findings were recently described by our group in patients with type 1 diabetes, another autoimmune disease (24). In contrast, patients with systemic lupus erythematosus were shown to have increased levels of APRIL, being related to the increased proinflammatory cytokines, IL-17 and IFN- $\gamma$ (18). Although several studies have related APRIL both to the regulation network and pathogenesis of different inflammatory diseases, it is not yet completely characterized how this cytokine is able to interfere with the immune response $(12,18)$. A significant positive correlation between APRIL levels and age (Fig 2A), shows an interesting profile of this cytokine. In our study, $50 \%$ of HT patients were over 55 years of age, all were treated with $\mathrm{FT} 4$ and had a good prognosis of the disease. Fabris and collaborators showed that APRIL was undetectable in the majority of HT patients with subclinical hypothyroidism, while the FT4-treated patients did not differ from healthy donors. They suggested that APRIL levels can be normalized under FT4-therapy (19). Our patients were also in treatment with T4, however, we found that APRIL levels were decreased considering healthy donors.

In this sense, several clinical trials have demonstrated the efficacy of the BAFF/APRIL blockade which showed considerable variability in the response to B cell-targeted therapy $(29,30)$. APRIL promotes $B$ cell survival and differentiation, which involves intricate regulatory mechanisms according to the varieties of the receptors (BCMA or $\mathrm{TACl}$ ) and the differentiation stage of $\mathrm{B}$ cells. Further studies are required to better understand the participation of APRIL in the regulatory phenotype of these cells, which would favor the development of new therapies in patients in early stages of HT.

\section{Acknowledgements:}

he authors would like to thank Dr. Possídio

Gomes Campos Junior (Dom Bosco Clinical Laboratory, Rio de Janeiro, Brazil) for providing the

\section{BIBLIOGRAPHIC REFERENCES}

Pyzik A, Grywalska E, Matuszek B, Rolinski J. Immune Disorders in Hashimoto's Thyroiditis: What Do We Know So Far? J Immunol Res. 2015: 979167. doi: 10.1155/2015/979167.

Antonelli A, Ferrari SM, Corrado A, Di Domenicantonio A, Fallahi P. Autoimmune thyroid disorders. Autoimmun Rev. 2015;14:174-180.

Chistiakov DA. 2005 Immunogenetics of Hashimoto's thyroiditis. J Autoimm Dis. doi: 10.1186/1740-2557-2-1. Pearce EN, Farwell AP, Braverman LE. Thyroiditis. N Engl J Med. 2003;348:2646-2655. 
Cooper DS, Biondi B. Subclinical thyroid disease. Lancet. 2012;379:1142-1154.

Effraimidis G, Wiersinga W. Mechanisms in endocrinology: autoimmune thyroid disease: old and new players. Eur J Endocrinol. 2014;170:241-52.

Ben-Skowronek I, Szewczyk L, Kulik-Rechberger B, Korobowicz E. The differences in T and B cell subsets in thyroid of children with Graves' disease and Hashimoto's thyroiditis. World Journal of Pediatrics. 2013;9(3):245-250.

Korn T, Bettelli E, Oukka M, Kuchroo VK. IL-17 and Th17 cells. Annual Review of Immunology. 2009;27:485-517.

Shen P, Roch T, Lampropoulou V, O'Connor RA, Stervbo U, Hilgenberg E, et al. IL-35-producing B cells are critical regulators of immunity during autoimmune and infectious diseases. Nature. 2014;507(7492):366-370.

Naradikian MS, Perate AR, Cancro MP. BAFF receptors and ligands create independent homeostatic niches for B cell subsets. Curr Opin in Immunol. 2015;34:126-9.

Bossen C, Schneider P. BAFF, APRIL and their receptors: structure, function and signaling. Seminars in immunology. 2006;18(5):263-275.

López-Fraga M, Fernández R, Aebar J.P, Hahne M. Biologically active APRIL is secreted followed intracellular processing in the Golgi apparatus by furin convertase. EMBO reports. 2001;3:945-951.

Hahne M, Kataoka T, Schröter M. APRIL, a new ligand of the tumor necrosis factor family, stimulates tumor cell growth. J Exp Med. 1998;188:1185-1190.

Morel J, Roubille C, Planelles L, Rocha C, Fernandez L, Lukas C, et al. Serum levels of tumor necrosis factor family members a proliferation-inducing ligand (APRIL) and B lymphocyte stimulator (BLyS) are inversely correlated in systemic lupus erythematosus. Ann Rheum Dis. 2009;68:997-1002.

Tan SM, Xu D, Roschke V, Perry JW, Arkfeld DG, Ehresmann GR, et al. Local production of B lymphocyte stimulator protein and APRIL in arthritic joints of patients with inflammatory arthritis. Arthritis Rheum. 2003;48:982-992.

Fernandez L, Salinas GF, Rocha C, Carvalho-Pinto CE, Yeremenko N, Papon L, et al. The TNF family member APRIL dampens collagen-induced arthritis. Ann Rheum Dis. 2012;72(8):1367-1374.

Boghdadi G, Elewa EA. Increased serum APRIL differentially correlates with distinct cytokine profiles and disease activity in systemic lupus erythematosus patients. Rheumatol Int. 2014;34:1217-1223.

Fabris M, Grimaldi F, Villalta D, Piciemo A, Fabro C, Bolzan M, et al. BLyS and April serum levels in patients with autoimmune thyroid diseases. Autoimmunity Reviews. 2010;9:165-169.

Jagessar SA, Fagrouch Z, Heijmans N, Bauer J, Laman JD, Oh L, et al. The different clinical effects of anti-BLyS, anti-APRIL and anti-CD20 antibodies point at a critical pathogenic role of $\gamma$-herpesvirus infected $B$ cells in the marmoset EAE model. J Neuroimmune Pharmacol. 2013,8:727-738.

Stone MB, Wallace RB. Medicare Coverage of Routine Screening for Thyroid Dysfunction. doi: 10.17226/10682.

Brenta G, Vaisman M, Sgarbi JA, Bergoglio LM, Andrada NC, Bravo PP, et al. Clinical practice Guidelines for management of hypothyroidism. Arq Bras Endocrinol Metab. 2013;57(4):265-299.

Mariño E, Villanueva J, Walters S, Liuwantara D, Mackay F, Grey S. CD4+CD25+ T-cells control autoimmunity in the absence of B-cells. Diabetes 2009.58(7):1568-1577.

Carvalho-Santos A, Ribeiro-Alves M, Cardoso-Weide LC, Nunes J, Kuhnert LRB, Xavier AR, et al. (2015) Decreased

Circulating Levels of APRIL: Questioning Its Role in Diabetes. PLoS ONE 10(10): e0140150.

doi:10.1371/journal.pone.0140150.

Dillon SR, Gross JA, Ansell SM, Novak AJ. An APRIL to remember: novel TNF ligands as therapeutic targets. Nat Rev Drug Discov. 2006;5:235-246.

Yu G, Boone T, Delaney J, Hawkins N, Kelley M, Ramakrishnan M, et al. APRIL and TALL-1 and receptors BCMA and TACI: system for regulating humoral immunity. Nature Immunology. doi:10.1038/79802.

Litinskiy MB, Nardelli B, Hilbert DM, He B, Schaffer A, Casali P, et al. DCs induce CD40-independent immunoglobulin class switching through BLyS and APRIL. Nat Immunol. 2002;3(9):822-829.

Vincent FB, Morand EF, Schneider P, Mackay F. The BAFF/APRIL system in SLE pathogenesis. Nature Reviews Rheumatology. doi:10.1038/nrrheum.2014.33.

Chen M, Lin X, Liu Y, Li Q, Deng Y, Liu Z, et al. The function of BAFF on T helper cells in autoimmunity. Cytokine Growth Factor Rev. 2014;25:301-305.

30. Nakayamada S, Tanaka S. BAFF- and APRIL-targeted therapy in systemic autoimmune diseases. Inflammation and Regeneration. doi: 10.1186/s41232-016-0015-4. 